\title{
Decision Making Styles Of School Managers According To Their Individual Perception*
}

\section{Cennet KURBAN **}

\author{
Metin YAŞAR ${ }^{* * *}$
}

Accepted: 04 May 2016

\begin{abstract}
In this study, decision making styles of school managers were identified and whether there is a significant relationship between identified demographic variables and decision making styles. Study population is formed by the school managers in the province of Denizli. The sample consists of 163 school managers, 247 deputy managers; in the total of 410 school managers who are working in 19 districts across the city of Denizli, selected by stratified sampling method.In the study, Decision Making Style Questionnaire for collecting information and Personal Information Form is used.The conclusion has been reached that the majority of school managers participating in the study are rational decision makers. The rest of the participants have been categorized as respectively intuitive decision-makers, dependent decision-makers, avoidance decision-makers. As a result of analysis, a significant relationship could not be found between demographic variables and decision making styles.
\end{abstract}

Keywords: rational, intuitive, dependent, self-1nstant, avoidance.

\section{Extended Abstract}

Purpose and Significance: Decision making is the mental process of choosing from a set of alternatives and every decision-making process produces an outcome that might be an action, a recommendation, or an opinion.School managers and leaders adopt different styles of decision making based on their personality, the situation they face, the culture of the organization, characteristics of the people they are working with, and the nature of the decision itself.These decision style characteristics provide the necessary base for applications to improve communication, planning, goal setting, leadership style, and team building (Driver, Brousseau \& Hunsaker, 1990).

Like personality traits, these styles do not have perfect predictive power, but instead represent likelihoods of behavior across situations and domains. That is, a person scoring high on a particular decision-making style, such as Spontaneity, when needing to make a decision can be expected to act in a spontaneous manner more often than in a thoughtful and deliberate one.The number of styles of decision-making is subject to debate (Leykin \& DeRubeis, 2010, p. 506).

\footnotetext{
This study is a part of the first author's master's thesis entitled, "Decision Making Styles Of School Managers According To Their Individual Perception" and completed at Pamukkale University. This study was done by the consultancy of Metin Yaşar. Also a part of this study was presented as an oral presentation at the International Management Research Congress on 20-21 March 2016.

** Corresponding Author: PhD Student, Pamukkale University, Denizli, Turkey, cennet_kurban@mynet.com

**** Assist. Prof. Dr., Pamukkale University, Denizli, Turkey, myasar@pau.edu.tr
}

Citation Information

Kurban, C. \& Yaşar, M. (2017). Bireysel karar verme stillerine göre okul yöneticilerinin karar verme stilleri. Kuramsal Eğitimbilim Dergisi [Journal of Theoretical Educational Science], 10(1), 170-190 . 
Decisive. People using the decisive style value action, speed, efficiency, and consistency. Once a plan is in place, they stick to it and move on to the next decision (Driver et. al., 1990, p.113).

Flexible. Like the decisive style, the flexible style focuses on speed, but here the emphasis is on adaptability. Faced with a problem, a person working in the flexible mode will get just enough data to choose a line of attack and quickly change course if need be.

Hierarchic. People in the hierarchic mode do not rush to judgment. Instead, they analyze a great deal of information and expect others to contribute and will readily challenge others' views, analyses, and decisions (Driver et. al., 1990, p. 113).

Integrative. People using the integrative style don't necessarily look for a single best solution. Their tendency is to frame any situation very broadly, taking into account multiple elements that may overlap with other, related situations (Driver et. al., 1990, p. 114).

Systemic. Integrative and Hierarchic styles applies to the Systemic style which includes habits and traits of both of these styles. Systemics tend to define problems rather broadly (Driver et. al., 1990, p. 114).

Scott and Bruce in 1995 described decision making styles as the learned, habitual response pattern exhibited by an individual when confronted with a decision situation. With more attention to individual differences in decision making style Scott and Bruce (1995) considered five decision making styles as the General Decision Making Style that we measured these five styles among the school managers in this study (Thunholm, 2004).

The rational decision-making style is characterized by a comprehensive search for information, and logical evaluation of alternatives. A prominent feature of the rational style is to make decisions in a logical and systematic way, and to consider various options in terms of a specific goal.

Typical for the intuitive style is a tendency to rely on instincts, inner feelings and reactions. It is characterized by making decisions based on what feels right, rather than to have a rational reason for it. Attention is given to details in the flow of information, rather than systematic search for and processing of information.

The dependent style is characterized by a search for guidance and support from other people when making important decisions. Typical for the dependent style is to rarely make important decisions without consulting other people, and to often use the advise of others in decision-making situations.

The avoidant style is characterised by a tendency to postpone decision-making whenever possible and to make last minute decisions. To avoid making important decisions until the pressure is on, is typical for the avoidant style, possibly because thinking about them leads to feelings of uneasiness.

The spontaneous style is characterized by feelings of immediacy and a desire to get through the decision-making process as quickly as possible. Quick and impulsive 
decisions are usually made, and the spontaneous decision-maker bases decisions on what seems natural at the moment (Thunholm, 2004).

In this study, decision making styles of school managers were identified and whether there is a significant relationship between identified demographic variables and decision making styles.Additionally, factor analysis of scale was conducted, the realibility of scale was tested.

Method: Study population is formed by the school managers in the province of Denizli. The sample consists of 163 school managers, 247 school deputy managers; in the total of 410 school managers who are working in 19 districts across the city of Denizli, selected by stratified sampling method. In the study, Decision Making Style Questionnaire for collecting information and Personal Information Form is used.

General decision-making styles were measured by Scott and Bruce (1995). The participants were asked to consider statements regarding how they go about making important decisions in general, both at work and in private. The inventory contained a total of 25 items, with five items measuring each of the general decision-making styles; Rational, Intuitive, Dependent, Avoidant and Spontaneous. A five step Likertscale with the answering-alternatives Strongly disagree, Disagree, Undecided, Agree and Strongly agree was used (Thunholm, 2004).

Results and Discussion: In the analysis of data, for each subscale of Decision Making Style Scale of descriptive statistics values were calculated and interpreted. Frequency and percentage distributions for the interpretation of data on demographic variables were examined. Relationship between the dependent variables and independent variables was evaluated and by Independent Samples t-test' and 'One Way ANOVA' and the comments have been made on results.

The conclusion has been reached that the majority of school managers participating in the study are rational decision makers. The rest of the participants have been categorized as respectively intuitive decision-makers, dependent decision-makers, avoidance decision-makers. As a result of analysis, a significant relationship could not be found between demographic variables and decision making styles. 


\title{
Bireysel Algılarına Göre Okul Yöneticilerinin Karar Verme Stilleri *
}

\author{
Cennet KURBAN ${ }^{* *}$
}

\author{
Metin YAŞAR ${ }^{* * *}$
}

Makale Kabul Tarihi: 04 Mayıs 2016

\begin{abstract}
ÖZ: $\mathrm{Bu}$ araştırmada okul yöneticilerinin karar verme stilleri belirlenmiş ve belirlenen demografik değişkenler ile karar verme stilleri arasında anlamlı bir ilişkinin olup olmadığı araştırılmıştır. Araştırma örneklemini Denizli il genelindeki 19 ilçede görev yapan, tabakalı örnekleme yöntemi ile seçilen 163 müdür ve 247 müdür yardımcısı olmak üzere toplam 410 okul yöneticisi oluşturmaktadır. Araştırmada bilgi toplama amaçlı Karar Verme Stilleri Ölçeği ve Kişisel Bilgiler Formu kullanılmıştır. Verilerin analizinde Karar Verme Stilleri Ölçeği’ nin her bir alt boyutuna ilişkin betimsel istatistik değerleri hesaplanmış ve yorumlanmıştır. Bağımsız değişkenler ile bağımlı değişkenler arasında ki ilişki Bağımsız Örneklem t-testi (Independent Samples "t" test) ve Tek Yönlü Varyans Analizi (One Way ANOVA) istatistiksel teknikleri kullanılarak analiz edilmiş olup ulaşılan bulgulara ilişkin yorumlar yapılmıştır. Araştırmaya katılan yöneticilerin çoğunluğunun rasyonel karar vericiler olduğu sonucuna ulaşılmıştır. Kalan katılımcılar sırasıyla sezgisel karar verici, bağımlı karar verici, kaçınma karar verici, kendiliğinden-anlık karar verici olarak kategorize edilmiştir. Yapılan analiz sonucunda demografik değişkenler ile karar verme stilleri arasında anlamlı bir ilişki bulunamamıştır.
\end{abstract}

Anahtar kelimeler: rasyonel, sezgisel, bağımlı, kendiliğinden-anlık, kaçınma.

\section{Giriş}

Değişen dünya şartları ve gelişen teknoloji ile birlikte okullar yeniden yapılandırılmakta ve öğrenci profili farklılaşmaktadır. Bu değişim okul yöneticilerinin işlerini zaman zaman kolaylaştırdığ almalarını gerektiren durumları da ortaya çıkarmaktadır. Bu durumda bir topluluk adına karar alacak olan yöneticilerin karar verme stillerinin belirlenmesinin önemli olduğu düşünülmektedir. Karar verme kavramı farklı uzmanlık alanlarından araştırıcıların ilgisini çekmiştir. Süreçteki farklılıkların önemli nedenlerinden biri de karar verme stilleridir. Driver (1990)'a göre karar verme stili öğrenilmiş bir alışkanlıktır ve bunda karara ulaşılırken seçeneklerin tanımlanması ve karar sırasında bilgiyi işleme stilleri arasındaki farklılıklar anahtar olmaktadır (akt. Taşdelen, 2002, s. 40 ).

Karar verme kavramına ilişkin konuların genelinde olduğu gibi karar verme stillerinde de genel geçer, evrensel bir karar verme stilleri sınıflandırmasından bahsetmek mümkün değildir (Tatum vd., 2003, s. 1007). Bu çerçevede birçok araştırmacı kendi bakış açısına göre farklı karar verme stilleri tanımlamıştır (Tekin, 2006, s. 73). Bu araştırmada ise Scott ve Bruce'un rasyonel, sezgisel, bağıml, kaçınmacı ve kendiliğinden-anlık olarak gruplandırdığı karar verme stileri kullanılmışır. Scott ve Bruce (1995) yapmış oldukları çalışmaların neticesinde, karar verme stillerinin birbirinden bağımsız oldukları fakat bu stillerin birbirinden tamamen

\footnotetext{
* Bu makale pamukkale Üniversitesi Eğitim Bilimler Enstitüsü "Bireysel Algılarına Göre Okul Yöneticilerinin Karar Verme Stilleri” adlı yüksek lisans tezinden yararlanılarak hazırlanmıştır. Yrd. Doç. Dr. Metin Yaşar danışmanlığında tamamlanmıştır. Ayrıca 20 Mart 2016 tarihinde Uluslararası Yönetim Araştırmaları Kongresinde bildiri olarak sunulmuştur.

** Sorumlu Yazar: Doktora Öğrencisi, Pamukkale Üniversitesi, Denizli, Türkiye, cennet_kurban@mynet.com

*** Yrd. Doç. Dr., Pamukkale Üniversitesi, Denizli, Türkiye, myasar@pau.edu.tr
} 
de farklı olmadıkları ve bireylerin önemli kararlarını verecekleri zaman tek bir stil kullanmadıkları, bunun yerine bütün bu stillerin bir kombinasyonunu kullandıkları sonucuna ulaşmışlardır (Thunholm, 2004, s. 933).

Örneğin karar alırken rasyonalist davranan mantıklı ve bilinçli kararlar alan bireylerin tutumlarının katılaşması bir süre sonra olası bir durum haline dönüşür. Oysa insan odaklı çalışma faktörünün etkin olduğu okullarda zaman zaman hislerin ve tecrübelerinde aktif kullanımını gerektiren durumlar söz konusu olur. Eğitimcinin öğrenciye karşı tutumunda, öğrencilerin gelişim dönemlerini de göz önünde bulundurulduğu bir karar sürecinde tamamen mantık ve bilincin baz alındığı kararlar her zaman işe yaramayabilir. Örneğin okul öncesi yaş grubunun veya ergenlik döneminde ki öğrencilerin bulunduğu okullarda bazen mantık sınırlarını zorlayan kararlar alınması zorunluluk haline gelebilmektedir. Okullar mantık, tecrübe ve şefkat gibi kavramları bir arada kullanabilen bireylerin daha fazla katkı sağlayabileceği kurumlardır.

Aynı zamanda hiyerarşik bir düzen içinde yönetmeliklerin uygulandığı kurumlar olan okullarda yöneticilerin belirli düzeyde üstlerine bağımlı kalarak karar alması olası bir durumdur. Fakat sürekli üstlerine bağımlı kalan, insiyatif alamayan yöneticiler, işlerin yavaşlamasına neden olmalarının yanında bir süre sonra çalışanların ve öğrencilerin gözünde saygınlıklarını kaybeden bireyler olacaklardır. Bağımlı karar veren özgüveni olmayan yöneticilerin, sorumluluk almaması değişime ve gelişime karşı bir çatışma ortamının oluşmasına neden olacaktır. Bu tür yöneticiler ellerinde bulunan yetkileri zor durumda kaldıklarında güç göstergesi olarak kullanacaklardır. Bu da çalışanlar açısında güvensiz bir çalışma ortamı oluşmasına neden olacaktır. Yöneticiye güvenmeyen çalışan, okuldaki öğrenci ve işleyiş ile ilgili sorunları kendisi çözmeye çalışacak, bu konuda yöneticiye bilgi vermeyecektir. Sorun çözülemeyince de daha büyük sorunlar oluşmasına neden olacaktır.

"Kaçınmacı karar veren kişilerin, yeni fikir ve aktivitelere karşı yavaş, kaygılı ve endişeli, risk almaktan kaçan, tanımadığı yabancı kişilerle iletişime girmekten kaçınan, sosyal ilişkilere isteksiz, insan ilişkilerinde mesafeli, erteleyici, çabuk pes eden, hedefleri tutarsız davranış gösteren kişiler olduğu anlaşılmıştır” (Üngüren, 2011,s. 311). Kararların ertelendiği, hatta zaman zaman karar almanın söz konusu bile olmadığı bir ortamda bu durumdan etkilenen bireyler için çözümü zorlaştırılan bir çok problem ortaya çıkacaktır.

$\mathrm{Bu}$ çerçevede eğitim kurumlarında karar verici olarak eğitim yöneticilerinin sahip olduğu karakteristik özellikleri, iç tepkisel denetim mekanizmaları, kendilerine olan saygıları ve içinde bulunduğu sosyokültürel çevre gibi değişkenlerin, yöneticilerin probleme yaklaşım tarzları ve karar verme stilleri üzerinde bir farklılık oluşturma durumlarının tespit edilmesi ve oluşturulacak kararların niteliğini arttırabilecek tedbirler alınması mevcut sistemi iyileştirici bir etken olacaktır.

\section{Karar Verme Stilleri}

Karar verme, Simon (1976) tarafından seçim davranışı olarak ifade edilmektedir. Buna göre, bireyin belli bir amaca ulaşmak için çeşitli seçenekler arasından özel bir 
tanesini bilinçli olarak seçme işlemidir."Karar verme" ve "Karar" tanımları birbirleriyle karıştırılmasına rağmen aralarında kesin olan bir fark vardır.Bu fark, karar'ın sadece sonucu ifade etmesi, karar verme'nin ise bir sürece sahip olmasıdır (akt. Altay, 2011, s.49).

Karar verme stili, karar alma durumunda bir kişinin yaklaşım, tepki ve eylemlerde bulunduğu duruma denir. Yani bireyin, karar vermesi gereken bir durumla karşılaştığında, nasıl davrandığı ve nasıl bir duruş sergilediği ile alakalı bir durumdur. Dolayısıyla bireylerin karar verme sürecindeki tutumu ve olaylara karşı tavrı önemlidir. Bireyin karar verme sorununa yaklaşımını ve karar verirken izlenen yöntemleri içeren karar verme stratejisi kararın niteliğini etkileyecektir (Kuzgun, 2000, s.87).

Driver karar verme stili. Driver, Brousseau ve Hunsaker (1990) karar verme stillerini beş grupta incelemişlerdir.

Kararlı stil (The Decisive Style). Driver ve arkadaşlarına (1990/2014, s.19) göre kararlı insanlar iş tanımı açıkça yapılmış organizasyonları tercih ederler. $\mathrm{Bu}$ organizasyonda her bir kişinin kendi amacı vardır ve kimsenin işi başkasının işi ile örtüşmemektedir. Kararlı insanlar dürüst, açık sözlü ve hilesiz kalarak diğer insanların saygısını ve hayranlığını kazanırlar. Karşı oldukları durumları açık ve net olarak ifade ederler.

Esnek stil (The Flexible Style). Esnek yöneticiler kararlı yöneticiler gibi bilgiyi sınırlı düzeyde kullanırlar. Fakat bu stilde aynı bilgi, bakış açılarına bağlı olarak farklı zamanlarda farklı şekillerde yorumlanır. Bu stilde diğerleri tarafından kabul görmek için hız, uyum sağlama ve eyleme geçme gibi nitelikler kullanılır. Beklentilere çabuk uyum sağlayabildikleri için kabul görmeleri neredeyse garantidir. Politikacılar gibi amaçları başkalarının isteklerine göre şekillenir. Esnekler genellikle izin ya da değişen koşullardan yararlanmayı ve kendilerini özgürce ifade etmelerini gerektiren satış veya moda tasarım gibi işlerde etkili çalışır (Driver vd., 1990, s.23).

Hiyerarşik stil (The Hierarchic Style). Driver ve arkadaşlarına (1990/2014, s.26) göre hiyerarşik stilde en iyi sonuca ulaşmak için bilgi üst düzeyde kullanılır. Kalite ve mükemmelliğe odaklanılır. Bir ürünün kalitesini azaltabilecek hiçbir detay göz ardı edilmez. Hedefe ulaşmak için, azami bilginin kullanıldığı, özenle tasarlanan ve kontrol edilen işler geliştirilir. Hiyerarşik stilin kötü yönü bu insanların insiyatif alamayan diktatör yöneticilere dönüşmeleridir.

Bütünleştirici stil (The Integrative Style). Hiyerarşik stilde olduğu gibi bütünleştirici stilde de bilgi kullanımı çok fazladır. Keşif ve yaratıcılığa değer verirler. Detaylı veri analizini içeren uzun vadeli planlar yaparlar. Fakat bu planlar değişen şartlara göre tekrar düzenlenir. Bilgi işleme alışkanlıkları, geniş vizyonları ve sahip oldukları uzmanlıklar önemli bir güç ve nüfuz kazandırır. Yönetici olarak astları karara katma taraftarıdırlar. Sezgi, gerçeklik ve fikirleri eşit şekilde dikkate alırlar (Driver vd., 1990, s.30). 
Sistemik stil (The Systemic Style). Sistemik stil Driver ve arkadaşlar1 (1990/2014, s.34) tarafından beş stil arasında kavraması en zor ve en kompleks olan stil olarak tanımlanır. Bütünleştirici ve hiyerarşik stili kombine eden sistemikler, hem çok odaklı hem de tek odaklıdır. Birleştirici uzak hedefler açısından tek odaklıyken, farklı alt hedefleri veya uzak hedeflere yol gösterici olan, çeşitli taktik ve stratejileri içeren amaçları kapsaması açısından çok odaklıdır. Sistemik tipteki plan, sorunlar ile başa çıkmak, birden fazla öncelik ve ayrıntılı stratejiler üretmek için çok fazla detaylandırılır. Hiyerarşi, sistemik stilin bir parçası olmasına rağmen, planlar uzun vadeli olmayabilir. Pazarlama kampanyası veya üretim sürecini gösteren diyagram, harita, resim, araçgereçler ve bütün ayrıntıları büyük resimde göstermeye çalışan grafik sunumları iş alanında sistemik stilin kullanıldığının belirtileridir (Driver vd., 1990, s.34).

Johnson karar verme stili. Johnson karar stillerini bilginin toplanması ve analiz edilmesi açısından incelemiştir.

Bilginin toplanması (Gathering Information). Johnson (1978/2014,s. 531) tarafından yapılan araştırmada Bilgi toplamanın iki temel süreçten oluştuğu belirlenmiştir. Bu süreçler anlık (Spontaneous) stil ve sistematik (systematic) stil olarak tanımlanmıştır.

Anlık stil (Spontaneous). Olayları bütün olarak ele alıp genel bir tepki verirler. Bir işi keşfederken eski deneyimlerinin onları bu konuda gelecekte de yardımcı olabileceğini düşünürler. Psikolojik olarak çabuk bağlanırlar. Değerlendirecekleri her alternatifi içselleştirirler. Aynı zamanda yeni bir ilgi alanı bulduklarında bağımlılıkları hızlı bir şekilde bu alana kayar. Bu stilde herhangi bir konuya, düşünceye veya hedefe odaklanma güç bir durumdur. Anında bir konudan başka bir konuya geçebilirler (Johnson, 1978/2014, s. 532).

Sistematik stil. Olaylara kollektif tepki, temkinli psikolojik bağlılık ve sistemli hedef yönelimi sistematik bilgi toplayan kişilerin temel özellikleridir. Olaylara kollektif tepki veren bireyler, herhangi bir deneyimi yaşamadan önce detaylı bilgi edinmeyi tercih ederler. Her alternatifi değerlendirirler ve sadece yaptıkları seçimi içselleştirirler. Yeni olan her fikre, düşünceye ve eyleme karşı temkinli yaklaşırlar. Sistematik ve anlık stil arasındaki en önemli fark, anlık karar vericilerin öncelikle psikolojik bağlanma gösterip, sonrasında emin olmak için bilgi toplamalarıdır. Diğer taraftan sistematik karar vericiler bütün bilgiler toplanmadıkça psikolojik bağlılık göstermezler. Birden fazla hedefle aynı anda ilgilenebilecekken, önce tek bir hedefi gerçekleştirip daha sonrasında diğer hedefe yönelmeyi tercih ederler. Gerektiğinde esnek olup planlarını değiştirebilirler, ama öncelikleri yeni planlar için hedef belirlemek olacaktır (Johnson, 1978/2014, s. 532).

Veri analizi. Bu aşama içsel ve dişsal olmak üzere iki süreci içerir.

Dışsal (External). Johnson (1978/2014,s.533) bu insanların herhangi bir konuda fikir sahibi olmak için öncelikle konuşmayı tercih ettiklerini belirtiyor. Topladıkları bilgileri konuşmak için firsat arayan dişsal karar vericilerin, ne düşündüklerini anlamak 
için konuşmalarını dinlemek gerekir. Bu kişiler bir fikir üzerinde düşünürken aynı anda konuşabilirler. Dışsal süreci analiz edebilmenin en iyi yolu ne kadar çok konuştuklarına değil, ne konuştuklarını dikkate almaktır.

Íçsel (Ínternal). Bu stilin temel özelliği herhangi bir konuda konuşmadan önce o konu üzerinde uzun bir süre düşünmeleridir. İçsel karar vericiler az konuşurlar ve konuştuklarında da büyük anlaşmalar üzerine konuşurlar. Dışsal ve içselleri ayırt edebilmenin en iyi yolu konuşmalarına odaklanmaktır (Johnson,1978, s.533).

Rowe Karar Verme Stili. Rowe'un yaklaşımının temelinde Jung teorisi yatmaktadır. Bu yaklaşımın Mitroff ve Kilman modeliyle benzerlikler gösterdiği söylenebilir. Bu yaklaşıma göre karar verme stilleri aşağıdaki gibi açıklanmaktadır (akt. Nas, 2006, s.80-81).

Drektif stil (The Directive Style). Bireyin belirsizlik konusunda tahammülü düşüktür. Değerler ölçeğinin teknik yanına odaklanma eğilimindedir. Bu stildeki insan otokratik yapıya sahiptir ve güce ihtiyacı vardır. Çünkü az bilgi ve seçenek kullanır. Hızlı ve tatminkar karar bu tipin genel özelliğidir. Direktif yöneticiler kendi ortamlarında yapısal durum ve sözel olarak verilen detaylı bilgiyi tercih etme eğilimindedir. Prosedürleri takip etme ve saldırgan yapıda olmaya meyillidirler. Örgütlerinin içerisine odaklanarak sıkı ve yakın kontrol kurarlar. Genellikle "diğeri" üzerinde baskı kurarak onu yönetmek isterler.

Analitik Stil (The Analytic Style). "Direktif” karar vericilere nazaran belirsizliğe tahammülleri daha fazladır. Bilişsel olarak karmaşık bir kişiliğe sahiptir. Bu sayede direktif stildekinden daha fazla bilgi miktarını ve daha fazla seçeneği dikkate alır. Teknik değer intibakı sayesinde yeni durumlara cevap verebilme konusunda örnek bir tip oluşturur. $\mathrm{Bu}$ stil, problem çözme ve verilen her durumda başarıyı maksimuma ulaştırabilmek için çabalama eğilimindedir. Bu tipin en belirgin özelliği birçoğunun bulunduğu ortamda en üst mertebeye ulaşabilmesidir. Değişiklikten ve yazılı raporlardan hoşlanır.Diğer özellikleri ise; tümden gelimci düşünmesi, özetlemede iyi olması, yenilikçi olması, meydan okumadan hoşlanması olarak sıralanabilir.

Kavramsal stil (The Conceptual Style). Hem bilişsel karmaşaya hem de insanlara odaklanması, çok veri kullanmasını dolayısıyla sistem yönlü olmasını sağlamaktadır. Bu yönetici birçok alternatifi dikkate alır. Davranış stilinde olduğu gibi ilişskilerinde dürüstlük ve açıklık ayrıca amaçlarını ekibiyle paylaşması ortak özellikleridir. Kavramsal yöneticiler birçok seçeneği ve kalitelerini değerlendirerek mükemmeliyetçi olmaya çalışırlar. Çözümlerinde yaratıcı olamaya çalışırlar. Karmaşık ilişkileri hayal güçleri ile çözümleyebilirler. Onları ilgilendiren şey uzun sürede çözülebilecek problemlerdir. Örgütsel vatandaşlık yönleri kuvvetlidir. Başarı yönlüdürler ve övgüye, kabul edilmeye, bağımsızlığa değer verirler. Güç için esnek kontrolü ve katılımcı olmayı sıklıkla tercih ederler. 
Davranışsal stili (The Behavioral Style). Düşük bilişsel karmaşıklık seviyesinde iken bu yöneticiler örgüt ve insanların gelişimi gibi olaylarla derinlemesine ilgilenir. Davranışsal stilli yöneticiler diğerlerini destekleme eğilimindedir. Danışılmasından hoşlanır. Önerileri kabul etmesi sayesinde kolay iletişim kurar, samimiyet gösterir, empati yapıcıdır, iknacıdır, gevşek kontrolü kabul eder. Az bir veri girişiyle, iletişim için toplantıları kullanarak, kısa ve orta vadeli süreçlerde yoğunlaşma eğilimindedir. Bu yöneticiler çatışmaları önler, uzlaşmayı arar ve çok insan yönlüdürler.Fakat bazen kendini güvensiz hissederler.

Scott ve Bruce karar verme stilleri. Scott ve Bruce (1995) karar vermede, karar verme görevi ve çevrenin etkisinden daha çok, karar verme davranışındaki münferit farklarla ilgilenmişler ve beş farklı karar verme stili tanımlamışlardır. Bunlar (akt. Taşdelen, 2002, s. 29):

Rasyonel stil (Rational). Karar vermeye mantıksal ve yapısal bir yaklaşımın olduğu durumdur.

Sezgisel stil (Intuitive). Karar vermede sezgilerin, duyguların ve diğer soyut faktörlerin etkin olduğu durumdur.

Bağımlı stil (Dependent). Karar vermede diğer kişilerin yönlendirme ve desteğinin etkin olduğu durumdur.

Kaçınma stili (Avoidant). Karar verme davranışından kaçınmanın ve karar vermeyi ertelemenin baskın olduğu durumdur.

Kendiliğinden-Anlık stil (Spontaneous). Fazla düşünmeksizin ve ani karar verme davranışının baskın olduğu durumdur

\section{Araştırmanın Amacı}

$\mathrm{Bu}$ çalışmadaki genel amaç, eğitim yöneticiliğinde karar verme stillerinin önemini ortaya koymaktadır. Yöneticilerin sorunlara yaklaşımında ki bireysel tarzlarını etkileyen faktörler, aynı zamanda örgütlerin gerçekleştirilebilir hedefler belirlemesinde ve hedeflerin sonuca ulaşmasında da etkilidir. Karar sürecinin etkin yönetimi ve karar aşamasındaki tutumu, bir yöneticinin başarı grafiğini olumlu ya da olumsuz yönde etkileyebilir. Her şeyden önce bu süreçte yöneticinin kişilik özellikleri, bilişsel kazanımları, aldığ 1 eğitim ve olaylara yaklaşım tarzı vereceği karar üzerinde etkin bir sonuç oluşturacaktır. Eğer bu süreç başarılı bir şekilde yönetilemiyorsa eksiklerin tespit edilmesi ve tamamlanması aşamasında yol gösterici olması açısından bu çalışmanın faydalı olabileceği düşünülmektedir. 


\section{Yöntem}

\section{Araştırma Modeli}

Araştırma, ilişkisel tarama modelindedir.Mevcut durum betimlenmiş ve buna bağlı olarak değişkenlerin birbirleriyle ne düzeyde ilişkili olduğu incelenmiştir.

\section{Çalışma Grubu}

Araştırma evrenini Denizli il genelinde 19 ilçede görev yapan 406' s1 müdür ve 614'ü müdür yardımcısı olmak üzere toplam 1020 okul yöneticisi oluşturmaktadır.Daha homojen olacak şekilde 19 ilçede görev yapan yönetici sayıları göz önünde bulundurularak 19 tabaka (alt evren) oluşturuldu. Tabakalı örneklemde, örneklem büyüklüğü Yazıcıoğlu ve Erdoğan (2004) tarafından araştırmalarda kolaylık sağlamak amacıyla oluşturulan tablodan yardım alınarak 1020 kişilik evrene en az 406 kişi olarak belirlendi.

Tabaka ağırlığı: Örneklem büyüklüğü / Evren büyüklüğü

Tabaka ağırlı̆̆ı: $406 / 1020=0,398$

$\mathrm{Bu}$ formüle dayalı olarak tabaka ağırlığı 0,398 bulunmuştur. Böylece çalışma evrenin \%39.8 i alınarak, örneklem büyüklüğü olan 406 kişi 19 ilçeye dengeli bir şekilde dağıtılmıştır."Evren büyüklüğ̈̈nün, 1.000 ile 2.500 arasında olan gruplarda \%3 hata ile 406 kişinin evreni temsil ettiği varsayılmaktadır" (Yazıcığlu \& Erdoğan, 2004, s.25). Örneklem sayısı öngörülen örneklem sayısı ile aynıdır. $\mathrm{Bu}$ nedenle örneklem evreni temsil eder niteliktedir.

\section{Veri Toplama Araçları}

Karar Verme Stilleri Ölçeği (KVSÖ), bireylerin karar verme sürecinde sorunlara yaklaşırken kullandıkları karar verme stillerindeki bireysel farklılıkları ölçmek amacıyla Scott ve Bruce (1995) tarafından geliştirilmiştir.

Ölçek, Taşdelen (2002) tarafindan Türkçeye uyarlanmıştır. KVSÖ’ nin güvenirlik çalışması için iç tutarlılık katsayıları (Cronbach alpha) hesaplanmıştır. Ölçeğin beş alt boyutunun tek tek iç tutarlılık (Cronbach alpha) analizleri incelendiğinde; Rasyonel Karar Verme Stili Alt Ölçeğinin iç tutarlılık katsayısı alfa: .76, Sezgisel Karar Verme Stili Alt Ölçeğinin iç tutarlılık katsayısı alfa: .78, Bağımlı Karar Verme Stili Alt Ölçeğinin iç tutarlılık katsayısı alfa: .76, Kaçınan Karar Verme Stili Alt Ölçeğinin iç tutarlılık katsayısı alfa: .79, Kendiliğinden-Anlık Karar Verme Stili Alt Ölçeğinin iç tutarlılık katsayısı alfa: .79 ve 24 maddeli tüm ölçek için iç tutarlılık alfa: .74 bulunmuştur. Bu bulgular ölçeğin tutarlı olduğunun göstergesidir. Ayrıca alt ölçeklerin ve ölçeğin tümünün madde toplam korelasyonlarına bakılmıştır. Birinci alt ölçek için .39 ile .61, ikinci alt ölçek için .42 ile .66, üçüncü alt ölçek için .52 ile .60 , dördüncü alt ölçek için .31 ile .70 , beşinci alt ölçek için .37 ile .72 arasındadır. $\mathrm{Bu}$ bulgular maddelerin alt ölçeklerle anlamlı düzeyde ilişkili olduğunu ve anlamlı katk1 sağladıklarını göstermektedir. Ölçeğin tümünde ise korelasyonların .05 ve .47 arasında 
değiştiği, ilişkinin pozitif ve orta düzeyde güçlü olduğu görülmektedir (Taşdelen, 2002, s. 49).

\section{Uygulama}

Araştırmada kullanılacak olan veri toplama araçlarının uygulamaları için 20132014 eğitim- öğretim yılında, Pamukkale Üniversitesi Eğitim Fakültesi Dekanlığı' ndan ve Denizli İl Milli Eğitim Müdürlüğünden gerekli izin alınmıştır. Denizli Büyükşehir Belediyesine bağlı tüm ilçelerde bulunan okulların tamamına tek tek ulaşmanın çok zor olması ve bunun için yeterli zaman olmaması nedeniyle veri toplama sürecinin elektronik ortam aracılığıyla yürütülmesine karar verilmiştir. Bu aşamada veri toplama aracı araştırmacı tarafindan elektronik ortama aktarılmıştır. Veri toplama aracının nasıl doldurulacağ 1 ve araştırma hakkında bilgiler yöneticilere elektronik ortamdan ulaştırılmıştır. Okulların iletişim bilgileri Denizli İl Milli Eğitim Müdürlüğü Mebbis biriminden alınmıştır. Yaklaşık iki ay süren veri toplama sürecinde yöneticiler tarafından elektronik ortamda doldurulan ölçekler yine elektronik ortam aracılığıyla toplanmıştır. Ayrıca Pamukkale ve Merkezefendi ilçelerinde çalışan yönetici sayısını fazla olması nedeniyle belirlenen alt örnekleme sadece elektronik ortam aracılı̆̆ 1 ile ulaşılamamıştır. $\mathrm{Bu}$ ilçelerdeki okullara gidilerek veri toplama araçları araştırmacı tarafindan yöneticilere verilmiş ve toplamda 410 kişiye ulaşılmıştır.

\section{Verilerin Analizi}

Araştırmanın birinci alt probleminde, okul yöneticilerinin genel bir karar verme stilleri var mıdır? sorusuna cevap aranmıştır. Bu nedenle, Karar Verme Stilleri Ölçeği’ nin her bir alt boyutuna ilişkin betimsel istatistik değerleri (aritmetik ortalama, medyan ve standart sapma) hesaplanmış ve yorumlanmıştır.

Ölçek maddeleri; 'kesinlikle katılmıyorum' (1), 'katılmıyorum' (2), 'kararsızım’ (3), 'katılıyorum' (4), 'kesinlikle katılıyorum' (5) şeklinde sıralanmış likert tipi 5'li bir derecelemeye göre puanlanmaktadır. Her seçeneğe karşılık gelen puan aralıkları, 'kesinlikle katıliyorum' ( 4.20-5.00), 'katıliyorum' (3.40-4.19), 'kararsızım' (2.60-3.39), 'katılmıyorum' (1.80-2.59), 'kesinlikle katılmıyorum' (1.00-1.79) olarak belirlenmiştir. Demografik değişkenlere ilişkin verilerin yorumlanmasında frekans ve yüzde dağılımları ele alınmıştır.

Araştırmanın ikinci alt probleminde, cinsiyet, görev durumu, kadro durumu, eğitim yönetimi ile ilgili seminer ve kurslara katılma durumu, herhangi bir sendikaya üye olma durumu ile bağımlı değişkenler arasında ki ilişki Bağımsız Örneklem t-testi (Independent Samples "t" test) ile, üç ve daha fazla alt kategoriye sahip olan, okul türü, eğitim durumu, yaş, öğretmenlik kıdem yılı, yöneticilik kıdem yılı ve branş bağımsız değişkenlerinin bağımlı değişkenlerle ilişkisi ise Tek Yönlü Varyans Analizi ('One Way ANOVA') ile değerlendirilmiş ve sonuçlara ilişkin yorumlar yapılmıştır. 


\section{Bulgular}

\section{Uygulanan Karar Verme Stillerine Ait Betimsel Değerler}

Tablo 1 incelendiğinde karar verme stilleri ölçeğini yanıtlandıran 410 yöneticinin \%31.5'i rasyonel karar vericiler olarak kategorize edilmiştir. Kalan katılımcıların, \%29.76`sının sezgisel karar verici, \%16.54'ünün bağımlı karar verici, \%12.92‘sinin kaçınma karar verici, \%9.13 ‘ünün kendiliğinden-anlık karar verici olduğu sonucuna ulaşılmıştır.

Ölçeğin rasyonel alt boyutu betimsel açıdan incelendiğinde maddelere verilen cevapların çoğunlukla "katılıyorum" olduğu görülmektedir. Sezgisel alt boyutta "kararsızım", bağımlı alt boyutunda "katılıorum", kaçınma alt boyutunda "katılmıyorum", kendiliğinden-anlık alt boyutunda ise maddelere verilen cevaplar çoğunlukla "katılmıyorum" şeklindedir.

Tablo 1

Ölçeğin Alt Boyutlarına Ait Betimsel Değerler

\begin{tabular}{lccc}
\hline & $\overline{\mathrm{x}}$ & ss & $\%$ \\
\hline Rasyonel & 4.16 & 0.64 & 31.65 \\
Sezgisel & 3.28 & 0.85 & 29.76 \\
Bağımlı & 3.60 & 0.81 & 16.54 \\
Kaçınma & 2.06 & 0.80 & 12.92 \\
Kendiliğinden-Anlık & 2.47 & 0.80 & 9.13 \\
\hline
\end{tabular}

Tablo 2'de, maddeler için verilen yanıtların betimsel değerleri incelendiğinde M3, M4, M5 için katılımcıların ortalama olarak "kesinlikle katılıyorum" cevabını verdikleri görülmektedir.M1, M2 için katılımcıların ortalama olarak "katılıyorum” cevabını verdikleri görülmektedir. 
Tablo 2

Rasyonel Alt Boyutuna Ait Betimsel İstatistikler

\begin{tabular}{llcc}
\hline \multicolumn{1}{c}{ Maddelerin Boyutları } & $\overline{\mathrm{X}}$ & ss \\
\hline M4 & Karar vermem dikkatli düşünmemi gerektirir. & .905 \\
$\mathbf{M 5}$ & $\begin{array}{l}\text { Karar verirken belirli bir amaca yönelik değişik seçenekleri } \\
\text { göz önünde bulundururum. }\end{array}$ & 4.32 & .873 \\
M3 & Mantıklı ve sistematik bir yolla karar veririm. & .863 \\
M1 & $\begin{array}{l}\text { Karar vermeden önce emin olmak için bilgi kaynaklarımı iki } \\
\text { kere kontrol ederim. }\end{array}$ & 4.15 & .911 \\
M2 & Karar vermeden önce doğru gerekçelerim vardır. & 3.75 & 1.087
\end{tabular}

Tablo 3 incelendiğinde M6, M7, M9, M10 için betimsel değerlere katılımcıların ortalama olarak "kararsızım" cevabını verdikleri görülmektedir. M8 için katılımcıların ortalama olarak "katılıyorum" cevabını verdikleri görülmektedir.

Tablo 3

Sezgisel Alt Boyutuna Ait Betimsel İstatistikler

\begin{tabular}{lcc}
\hline \multicolumn{1}{c}{ Maddelerin Boyutları } & $\overline{\mathrm{X}}$ & SS \\
\hline M8 Genellikle doğruluğunu hissettiğim kararlar veririm. & 3.75 & 1.084 \\
M6 Kararlarımı verirken içgüdülerime güvenirim. & 3.24 & 1.121 \\
M10 Karar verirken içimden gelen duygu ve tepkilere güvenirim. & 3.19 & 1.114 \\
M7 Bir karar verirken sezgilerime güvenme eğilimindeyimdir. & 3.13 & 1.110 \\
M9 Kararlarımı verirken benim için akılcı bir nedenden daha çok, \\
$\quad$ verdiğim kararın doğruluğunu hissetmem daha önemlidir.
\end{tabular}

Tablo 4 incelendiğinde M11, M12, M13, M14, M15 için katılımcıların ortalama olarak "katılıyorum" cevabını verdikleri görülmektedir. 
Tablo 4

Bă̆ımlı Alt Boyutuna Ait Betimsel İstatistikler

\begin{tabular}{lcc}
\hline \multicolumn{1}{c}{ Maddelerin Boyutları } & $\overline{\mathrm{X}}$ & ss \\
\hline $\begin{array}{l}\text { M14 Önemli kararlar ile yüzleştiğim zaman birinin bana doğru yolu } \\
\text { göstermesi hoşuma gider. }\end{array}$ & 3.86 & .996 \\
M13 Önemli kararlarımı alırken başkalarının tavsiyelerinden & & 1.025 \\
$\quad$ yararlanırım. & 3.79 & 1.061 \\
M15 Önemli kararlarımı başka insanlara danışmadan verdiğim nadirdir & 3.53 & 1.190 \\
M12 Eğer başkalarının desteğine sahipsem önemli kararları almak benim \\
$\begin{array}{l}\text { için daha kolaydır. } \\
\text { M11 Önemli kararlar alırken başkalarının yardımına sık sık ihtiyaç } \\
\quad \text { duyarım. }\end{array}$ & 3.45 & 1.112 \\
\hline
\end{tabular}

Tablo 5' de Kaçınma alt boyutuna ait olan M16, M17, M18, M19, M20 için betimsel değerleri incelendiğinde katılımcıların ortalama olarak "katılmiyorum" cevabını ve M24 için ise "kesinlikle katılmıyorum" cevabını verdikleri görülmektedir.

Tablo 5

Kaçınma Alt Boyutuna Ait Betimsel İstatistikler

\begin{tabular}{lcc}
\hline \multicolumn{1}{c}{ Maddelerin Boyutları } & $\overline{\mathrm{X}}$ & ss \\
\hline $\begin{array}{l}\text { M16 Üzerimde baskı hissetmediğim sürece önemli kararlarımı } \\
\text { almaktan kaçınırım. }\end{array}$ & 2.34 & 1.201 \\
M18 Önemli kararları alma aşamasına gelinceye kadar karar vermeyi \\
$\quad \begin{array}{l}\text { sık sık ertelerim. } \\
\text { M19 Önemli kararlarımı, genellikle son dakikada veririm. }\end{array}$ & 2.20 & 1.128 \\
M20 Üzerinde düşünmek beni rahatsız ettiği için pek çok kararı & 2.12 & 1.112 \\
$\quad$ ertelerim. & 1.96 & .993 \\
$\begin{array}{l}\text { M17 Mümkün olduğunca kararlarımı ertelerim. } \\
\text { M24 Kararlarımı, sıklıkla düşünmeden veririm. }\end{array}$ & 1.95 & 1.007 \\
\hline
\end{tabular}

Tablo 6 incelendiğinde Kendiliğinden-Anlık alt boyutuna ait olan M23, M25 için betimsel değerlere katılımcıların ortalama olarak "kararsızım" cevabını verdikleri görülmektedir. M21, M22 için betimsel değerleri incelendiğinde katılımcıların ortalama olarak "katılmıyorum" cevabını verdikleri görülmektedir. 
Tablo 6

Kendiliğinden-Anlık Alt Boyutuna Ait Betimsel İstatistikler

\begin{tabular}{lcc}
\hline \multicolumn{1}{c}{ Maddelerin Boyutları } & $\overline{\mathrm{X}}$ & ss \\
\hline M25 Kararlarımı verirken, o anda doğal olan ne ise onu yaparım. & 2.90 & 1.211 \\
M23 Çabuk karar veririm. & 2.73 & 1.136 \\
M22 Kararlarımı, çoğunlukla o anda veririm. & 2.19 & .976 \\
M21 Genellikle ani kararlar veririm. & 2.06 & .993 \\
\hline
\end{tabular}

\section{Karar Verme Stillerinin Demografik Değişkenlere Göre Farklılaşıp}

\section{Farklılaşmadığına İlişskin Bulgular}

Tablo 7'de yönetici sayılarına baktı̆̆ımızda bayan yöneticilerin azınlıkta olduğu görülmektedir. $\mathrm{Bu}$ durum da bayanların yöneticiliği pek tercih etmediği sonucuna ulaşılabilir. Yöneticilerin kadro durumunda vekil olarak çalışan yöneticilerin çoğunluğunu köy okullarında çalışan müdür yetkili sınıf öğretmenleri oluşturmaktadır. Ayrıca araştırmaya katılan yöneticilerin büyük çoğunluğunun alanları ile ilgili eğitim almış olmaları kendilerini geliştirmek adına çaba göstermeleri açısından sevindirici bir durumdur.

Tablo 7

İki Alt kategorili Değişkenlere Ait Independent Samples t test Sonuçlart

\begin{tabular}{|c|c|c|c|c|c|c|c|c|c|c|c|c|}
\hline & & \multirow[t]{2}{*}{$n$} & \multicolumn{2}{|c|}{ Rasyonel } & \multicolumn{2}{|c|}{ Sezgisel } & \multicolumn{2}{|c|}{ Băğımlı } & \multicolumn{2}{|c|}{ Kaçıngan } & \multicolumn{2}{|c|}{$\begin{array}{l}\text { Kendiliğinden- } \\
\text { Anlık }\end{array}$} \\
\hline & & & $t$ & $P$ & $t$ & $p$ & $t$ & $p$ & $t$ & $p$ & $t$ & $p$ \\
\hline \multirow{2}{*}{ Cinsiyet } & Erkek & 348 & \multirow{2}{*}{-0.17} & \multirow{2}{*}{0.87} & \multirow{2}{*}{0.76} & \multirow{2}{*}{0.45} & \multirow{2}{*}{1.00} & \multirow{2}{*}{0.32} & \multirow{2}{*}{0.66} & \multirow{2}{*}{0.51} & \multirow{2}{*}{0.01} & \multirow{2}{*}{0.99} \\
\hline & Kadın & 62 & & & & & & & & & & \\
\hline \multirow[b]{2}{*}{ Görev } & Müdür & 163 & \multirow[b]{2}{*}{-0.39} & \multirow[b]{2}{*}{0.70} & \multirow[b]{2}{*}{0.17} & \multirow[b]{2}{*}{0.87} & \multirow[b]{2}{*}{0.57} & \multirow[b]{2}{*}{0.57} & \multirow[b]{2}{*}{-0.66} & \multirow[b]{2}{*}{0.51} & \multirow[b]{2}{*}{-0.51} & \multirow[b]{2}{*}{0.61} \\
\hline & $\begin{array}{l}\text { Müdür } \\
\text { Yrd. }\end{array}$ & 247 & & & & & & & & & & \\
\hline \multirow{2}{*}{ Kadro } & As1l & 361 & \multirow{2}{*}{0.45} & \multirow{2}{*}{0.65} & \multirow{2}{*}{0.62} & \multirow{2}{*}{0.54} & \multirow{2}{*}{1.67} & \multirow{2}{*}{0.10} & \multirow{2}{*}{0.36} & \multirow{2}{*}{0.72} & 114 & 026 \\
\hline & Vekil & 49 & & & & & & & & & -1.14 & 0.20 \\
\hline Sendika & Evet & 359 & & & & & & & & & & \\
\hline Üyeliği & Hayır & 51 & -1.52 & 0.13 & -1.09 & 0.28 & -0.02 & 0.98 & -0.40 & 0.69 & -0.64 & 0.52 \\
\hline Seminer- & Evet & 339 & & & & & & & & & & \\
\hline $\begin{array}{c}\text { Kurslara } \\
\text { Katılım }\end{array}$ & Hayır & 71 & -0.60 & 0.55 & -0.67 & 0.50 & 0.63 & 0.53 & 1.72 & 0.09 & 0.39 & 0.70 \\
\hline
\end{tabular}

Tablo 7'de iki alt kategorili değişkenlere ait analiz sonuçları incelendiğinde ölçeğin tüm alt boyutlarında, bu değişkenlerin tümü açısından 0.05 düzeyinde anlamlı bir farklılaşmanın oluşmadığı görülmektedir. 
Tablo 8

$\ddot{U} c ̧$ ve Daha Fazla Alt kategorili Değişkenlere Ait ANOVA Sonuçları

\begin{tabular}{|c|c|c|c|c|c|c|c|c|c|c|c|c|}
\hline & & \multirow{2}{*}{$n$} & \multicolumn{2}{|c|}{ Rasyonel } & \multicolumn{2}{|c|}{ Sezgisel } & \multicolumn{2}{|c|}{ Bağımlı } & \multicolumn{2}{|c|}{ Kaçıngan } & \multicolumn{2}{|c|}{$\begin{array}{c}\text { Kendiliğinden- } \\
\text { Anlık }\end{array}$} \\
\hline & & & $F$ & $p$ & $F$ & $p$ & $F$ & $p$ & $F$ & $p$ & $F$ & $p$ \\
\hline \multirow{5}{*}{ Okul türü } & Lise & 136 & \multirow{5}{*}{2.34} & \multirow{5}{*}{0.06} & \multirow{5}{*}{0.37} & \multirow{5}{*}{0.83} & \multirow{5}{*}{1.72} & \multirow{5}{*}{0.15} & \multirow{5}{*}{0.63} & \multirow{5}{*}{0.64} & \multirow{5}{*}{0.57} & \multirow{5}{*}{0.69} \\
\hline & Ortaokul & 151 & & & & & & & & & & \\
\hline & İlkokul & 77 & & & & & & & & & & \\
\hline & Anaokulu & 23 & & & & & & & & & & \\
\hline & Diğer & 23 & & & & & & & & & & \\
\hline \multirow{3}{*}{$\begin{array}{l}\text { Eğitim } \\
\text { Durumu }\end{array}$} & Ön Lisans & 30 & \multirow{3}{*}{1.75} & \multirow{3}{*}{0.16} & \multirow{3}{*}{2.38} & \multirow{3}{*}{0.07} & \multirow{3}{*}{1.52} & \multirow{3}{*}{0.21} & \multirow{3}{*}{0.64} & \multirow{3}{*}{0.59} & \multirow{3}{*}{2.12} & \multirow{3}{*}{0.1} \\
\hline & Lisans & 331 & & & & & & & & & & \\
\hline & $\begin{array}{l}\text { Yüksek } \\
\text { Lisans }\end{array}$ & 48 & & & & & & & & & & \\
\hline \multirow{4}{*}{ Yaş } & $21-30$ & 27 & \multirow{4}{*}{0.41} & \multirow{4}{*}{0.75} & & & & & & & & \\
\hline & $31-40$ & 162 & & & & & & & & & & \\
\hline & $41-50$ & 133 & & & T.1.19 & 0.01 & 1.10 & 0.0 & t & 0.00 & 1.00 & 0.17 \\
\hline & 51-üstü & 88 & & & & & & & & & & \\
\hline & $1-5$ & 4 & & & & & & & & & & \\
\hline & $6-10$ & 68 & & & & & & & & & & \\
\hline $\begin{array}{l}\text { Ögrretmenlik } \\
\text { Kıdem Yılı }\end{array}$ & $11-15$ & 102 & 0.31 & 0.87 & 1.72 & 0.15 & 1.33 & 0.26 & 1.32 & 0.26 & 0.17 & 0.95 \\
\hline & $16-20$ & 62 & & & & & & & & & & \\
\hline & 21-üstü & 174 & & & & & & & & & & \\
\hline & $1-5$ & 147 & & & & & & & & & & \\
\hline & $6-10$ & 78 & & & & & & & & & & \\
\hline $\begin{array}{l}\text { Yöneticilik } \\
\text { Kıdem Yılı }\end{array}$ & $11-15$ & 64 & 0.8 & 0.53 & 2.39 & 0.05 & 0.37 & 0.83 & 1.02 & 0.4 & 1.24 & 0.3 \\
\hline & $16-20$ & 48 & & & & & & & & & & \\
\hline & 21-üstü & 73 & & & & & & & & & & \\
\hline
\end{tabular}

21-30 yaş grubundaki yönetici sayısının diğer gruplara oranla az olmasının nedeni olarak öğretmenlerin mezun olduktan sonra uzun bir süre atanmayı beklemeleri ve yöneticilik sınavlarına katılım için belli bir süre öğretmen olarak çalışma şartı aranması gösterilebilir.

Tablo 8'de üç ve daha fazla alt kategorili değişkenlere ait analiz sonuçları incelendiğinde ölçeğin tüm alt boyutlarında, bu değişkenlerin tümü açısından 0.05 düzeyinde anlamlı bir farklılaşmanın oluşmadığı görülmektedir. 


\section{Sonuç ve Tartışma}

$\mathrm{Bu}$ araştırmada yöneticilerin karar verme stilleri belirlenmiş ve belirlenen demografik değişkenlerle karar verme stilleri arasında anlamlı bir ilişkinin olup olmadığı araştırılmıştır.

Karar verme stilleri ölçeğini yanıtlandıran 410 yöneticinin \%31.65'i rasyonel karar vericiler olarak kategorize edilirken kalan katılımcıların, \%29.76'sının sezgisel karar verici, \%16.54'ünün bağımlı karar verici, \%12.92‘sinin kaçınma karar verici, \%9.13 ünün kendiliğinden-anlık karar verici olduğu sonucuna ulaşılmıştır.

Yöneticilerin vermiş olduğu kararlarda, ağırlıklı olarak rasyonel karar verme stilini kullanması, karar vermeden önce, alternatifleri mantık silsilesi kapsamında dikkatlice değerlendirdikleri sonucunu ortaya çıkarmaktadır. Alternatiflere mantıksal yaklaşılması çoğunlukla alınan kararların sonuçlarını olumlu yönde etkileyen bir etkendir. Fakat söz konusu olan kurumlar okullar olunca bazen mantık süzgecinden geçirilen kararlar gelişim psikolojisinin ön planda tutulması gereken durumlarla çatışan sonuçlar ortaya çıkarmaktadır. Bireyin psikolojik gelişiminin de içinde olduğu bir alan olan eğitim kurumlarında çalışan yöneticiler zaman zaman materyalist mantığı arka plana bırakıp bireyin psikolojik durumunu iyileştirme adına sezgilerinde ön plana çıktığ1 kararlar alabilmektedir. Bu durumda rasyonel karar verme stiline çok yakın bir oranda sezgisel karar verme stilinin kullanılması şaşırtıcı bir durum değildir.

Bağımlı karar verme stilini ağırlıklı olarak kullanan yöneticiler, vermiş oldukları kararların sorumluğunu almak istemedikleri gibi çoğunlukla bu sorumlulukları çalışanlara yükleme çabasındadırlar. Hiyerarşik bir düzen içinde yönetmelikler kapsamında üstlerine bağlı olan okul yöneticilerinin zaman zaman bağımlı kararlar alma durumuyla karşı karşıya kalması olası bir durumdur. Fakat çoğunlukla amirine bağımlı çalışan yönetici bir süre sonra işlerin yavaşlamasına neden olacak ve bu durum çalışan motivasyonunu azaltacak etken durumları ortaya çıkaracaktır. Araştırma sonuçları incelendiğinde insiyatif alamayan bağımlı karar vericilerin oransal olarak üçüncü sırayı aldığ1 görülmektedir.

Her bireyin kullanmış olduğu karar verme stilleri, amaçlar ve sonuçlar üzerinde farklı etkiler oluşturmaktadır. Fakat burada karar verme stilleri birbirinden bağımsız olarak ele alınsa da; bu stillerin birbirinden tamamen de farklı olmadıkları ve bireylerin önemli kararlarını verecekleri zaman tek bir stil kullanmadıkları, bunun yerine bütün bu stillerin bir kombinasyonunu kullandıkları hususunun unutulmaması gerekmektedir (Thunholm, 2004, s.932).

Ölçeğin rasyonel alt boyutu betimsel açıdan incelendiğinde maddelere verilen cevapların çoğunlukla "katılıyorum" olduğu görülmektedir. Sezgisel alt boyutta "kararsızım", bağımlı alt boyutunda "katılıyorum", kaçınma alt boyutunda "katılmıyorum", kendiliğinden-anlık alt boyutunda ise maddelere verilen cevaplar çoğunlukla "katılmıyorum" şeklindedir. Kaçınma ve kendiliğinden-anlık alt boyutlarında ki maddelerin "katılmıyorum" olarak cevaplandırılması, okul yöneticilerinin kararlarını düşünerek aldıkları ve karar aşamasında plansız hareket etmedikleri şeklinde yorumlanabilir. 
Yöneticiler en çok "Karar vermem dikkatli düşünmemi gerektirir." İfadesine katılım göstermişlerdir. "Kararlarımı, sıklıkla düşünmeden veririm.” maddesi ise en az benimsenen seçenek olmuştur. Yöneticilerin bu ifadelere verdikleri cevaplar göz önünde bulundurulduğunda, karar alma aşamasından önce ön hazırlık yaptıkları sonucuna ulaşılabilir.

Araştırmada yer alan yöneticilere ait demografik bulgular, cinsiyet değişkenine göre incelendiğinde bayan yöneticilerin, bay yöneticilere göre azınlıkta kaldığı tespit edilmiştir. Jacoby (2005) karar verme stilleri ile teknolojinin kabul edilebilirlik düzeyi ve kullanımı arasındaki ilişkiyi incelediği araştırmasında bu durumu erkeklerin liderliğe daha fazla yatkın olması ile açıklamıştır. Fakat bu durum bayanların iş yaşamı dışında da sorumluluklarının fazla olması açısından değerlendirildiğinde, bütün sorumlulukları ile birlikte bir bayanın aslında bir çok işi yapabilecek güce sahip olduğu, kendisine firsat tanındığında birçok işin üstesinden gelebileceği, şeklinde bir yorum getirilmesi daha eşitlikçi bir tutum olacaktır. Araştırmada yapılan analiz sonucunda cinsiyet değişkeni ile karar verme stilleri arasında anlamlı bir ilişki bulunamamıştır. Ancak Shim (1998) bir tüketici olarak ergenlik dönemindeki gençlerin karar verme stillerini incelemiş ve cinsiyet değişkeni ile karar verme stilleri arasında anlamlı bir ilişki olduğu sonucuna ulaşmiştır.

Yöneticilerin eğitim durumu incelendiğinde yüzdelik dilimi en az olan grubun ön lisans mezunu olduğu, çoğunluğun ise lisans bitirdiği bulgusuna ulaşılmıştır. Pamukkale Üniversitesi tarafından okul yöneticileri ve denetmenleri için açılan Eğitim Yönetimi, Teftişi, Planlaması ve Ekonomisi tezsiz yüksek lisans programı, yüksek lisans mezunu eğitim yöneticilerinin sayısının her geçen yıl artmasını sağlamaktadır. Araştırmada yapılan analiz sonucunda eğitim durumu değişkeni ile karar verme stilleri arasında anlamlı bir ilişki bulunamamıştır. Uzunoğlu (2008) hakemlerin karar verme stillerini klasmanlarına ve bazı değişkenlere göre incelediği araştırmasında ise hakemlerin, öğrenim durumlarına bakılarak; kaçınma karar verme puanlarında lise mezunu hakemler ile yüksek lisans mezunu ve Beden Eğitimi ve Spor Yüksekokulu mezunu hakemler arasında önemli bir farklılık bulunduğunu ve bu farklılığın lise mezunu hakemlerin aleyhinde olduğunu tespit etmiştir. Dolayısı ile eğitim seviyesi azaldıkça; hakemlerin çekingen davranış gösterdikleri ve sorumluluk almaktan uzaklaşma eğiliminde oldukları sonucuna ulaşmıştır.

Üngüren (2011) beş yıldızlı konaklama ve tatil köyü işletmelerinde çalışan departman yöneticileri ile yaptığı çalışmada yüksek lisans ve üniversite düzeyinde eğitim seviyesine sahip yöneticilerin rasyonel karar verme puanlarının, lise düzeyinde eğitim seviyesine sahip yöneticilere göre anlamlı ölçüde yükselerek farklılaştığ 1 bulgusuna ulaşmıştır. Elde edilen sonuçlara dayanarak yüksek lisans ve lisans/önlisans düzeyinde eğitim seviyesine sahip yöneticilerin kararlarını genellikle rasyonel karar verme stiline dayanarak aldığ ; sezgisel, bağımlı, kaçınmacı ve kendiliğinden karar alma davranışları içerisinde çok sık bulunmadığı sonucuna ulaşılmıştır.

Araştırmaya katılan yöneticilerin çoğunluğu 31-40 yaş aralığındaki gruplardadır. 21-30 yaş grubundaki yönetici sayısının \%6.6 gibi küçük bir oranda olmasının nedeni 
olarak öğretmenlerin mezun olduktan sonra uzun bir süre atanmayı beklemeleri ve yöneticilik sınavlarına katılım için belli bir süre öğretmen olarak çalışma şartı aranması gösterilebilir. Yapılan araştırmada yaş değişkeni ile karar verme stilleri arasında anlamlı bir ilişki olmadığı bulgusuna ulaşılmıştır. İlmez (2010) bir kamu kurumundaki görevli yöneticilerin ve çalışanların liderlik stilleri ile karar verme stilleri arasındaki ilişkinin belirlenmesi üzerine yaptığı araştırmada Hava Kuvvetleri Komutanlığında çalışan yöneticilerin yaş değişkeninin kaçınma karar verme stillerine ilişkin algılarını etkilediği bulgusuna ulaşmıştır. 


\section{Kaynakça}

Altay, Ü. (2011). Yöneticilerin duygusal zeka düzeylerinin karar verme stillerine etkisi ve bir araştırma (Yayımlanmamış Doktora Tezi). İstanbul Üniversitesi Sosyal Bilimler Enstitüsü, İstanbul.

Driver, M. J., Brousseau, K. R., \& Hunsaker, P. L.(1990). The dynamic decisionmaker five decision styles for executive and business success. Harper \& Row: New York.

İlmez, M. (2010). Bir kamu kurumundaki görevli yöneticilerin ve çalışanların liderlik stilleri ile karar verme stilleri arasındaki ilişkinin belirlenmesi (Yayınlanmış Yüksek Lisans Tezi). Ufuk Üniversitesi Sosyal Bilimler Enstitüsü, İstanbul.

Jacoby, M. (2005). Relationship between principals' decision makings styles and technology acceptance \& use (Unpublished Doctoral Dissertation). University of Pittsburgh, Pittsburgh, United States of America.

Johnson R.H. (1978). Individual styles of decision making: A theoretical model for founseling. The Personnel and Guidance Journal, 56(9), 530-536.

Kuzgun, Y. (2000). Meslek danışmanlığı: Kuramlar, uygulamalar. Ankara: Nobel Yayınları.

Leykin Y. \& DeRubeis R.(2010). Decision-making styles and depressive symptomatology: Development of the decision styles questionnaire. Judgment and Decision Making, 5(7), 506-515.

Nas, S. (2006). Gemi operasyonlarının yönetiminde kaptanın bireysel karar verme süreci analizi ve bütünleşik bir model uygulaması (Yayınlanmamış Doktora Tezi). Dokuz Eylül Üniversitesi Sosyal Bilimler Enstitüsü, İzmir.

Rowe, A. J. \& Boulgarides, J. D. (1994). Managerial decision making. Prentice Hall: New Jersey.

Scott, S.G. \& Bruce, R.A. (1995). Decision making sytle, the development and of a new measure. Educational and Psychological Measurement, 55(5), 818-831.

Simon, H. (1976). Administrative behavior a study of decision: Making processes in administrative organization. New York, United States of America : The Free Press.

Taşdelen, A. (2002). Öğretmen adaylarının farklı psiko-sosyal değişkenlere göre karar verme stilleri (Yayınlanmamış Doktora Tezi). Dokuz Eylül Üniversitesi Eğitim Bilimleri Enstitüsü, İzmir.

Tatum, B.C., Eberlin, R., Kottraba, C. \& Bradberry, T. (2003). Leadership, Decision Making and Organizational Justice. Management Decision, 41(10), 1006-1016.

Tekin, Ö. A. (2009). Yönetimde karar verme: Batı antalya bölgesinde bulunan beş yıldızlı otel işletmelerindeki çeşitli departman yöneticilerinin karar verme stillerini tespit etmeye yönelik uygulamalı bir araştırma (Yayımlanmamış Yüksek Lisans Tezi). Akdeniz Üniversitesi Sosyal Bilimler Enstitüsü, Antalya.

Thunholm P. (2004). Decision-making style: Habit, style or both? Personality and Individual Differences, 36, 931-944. 
Uzunoğlu, Ö. U. (2008). Türk futbol hakemlerin karar verme stillerinin klasmanlarına ve bazı değişkenlere göre incelenmesi (Yayımlanmamış Yüksek Lisans Tezi). Selçuk Üniversitesi Sağlık Bilimleri Enstitüsü, Konya.

Üngüren, E. (2011).Psikobiyolojik kişilik kuramı ekseninde yöneticilerin kişilik özellikleri, karar verme stilleri ve örgütsel sonuçlara yansımaları (Yayınlanmamış Doktora Tezi). Akdeniz Üniversitesi Sosyal Bilimler Enstitüsü, Antalya.

Yazıcığlu, Y. \& Erdoğan, S. (2004). SPSS uygulamalı bilimsel araştırma yöntemleri. Ankara: Detay Yayıncılık. 